\title{
cäablovasdla Diseases
}

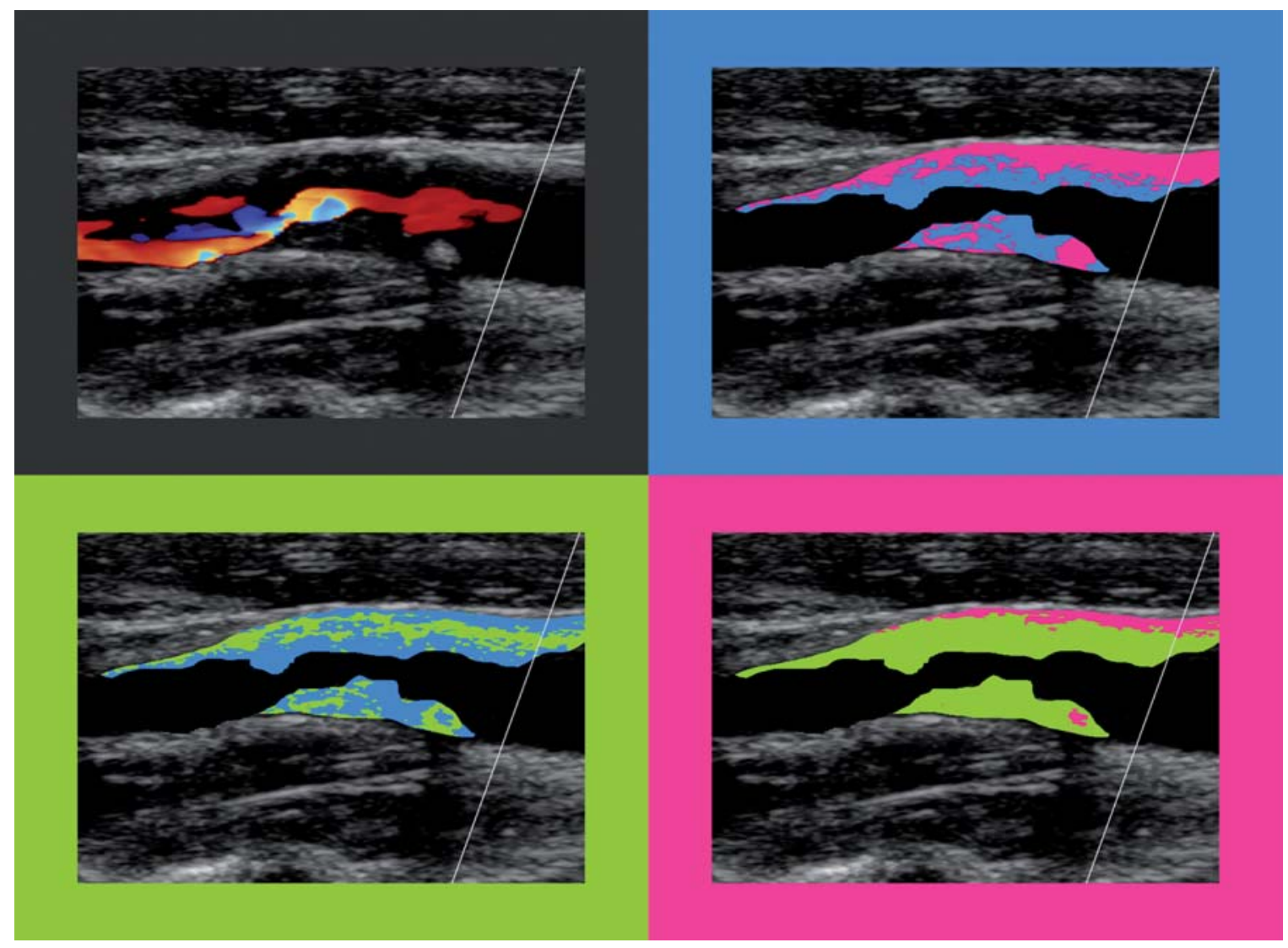




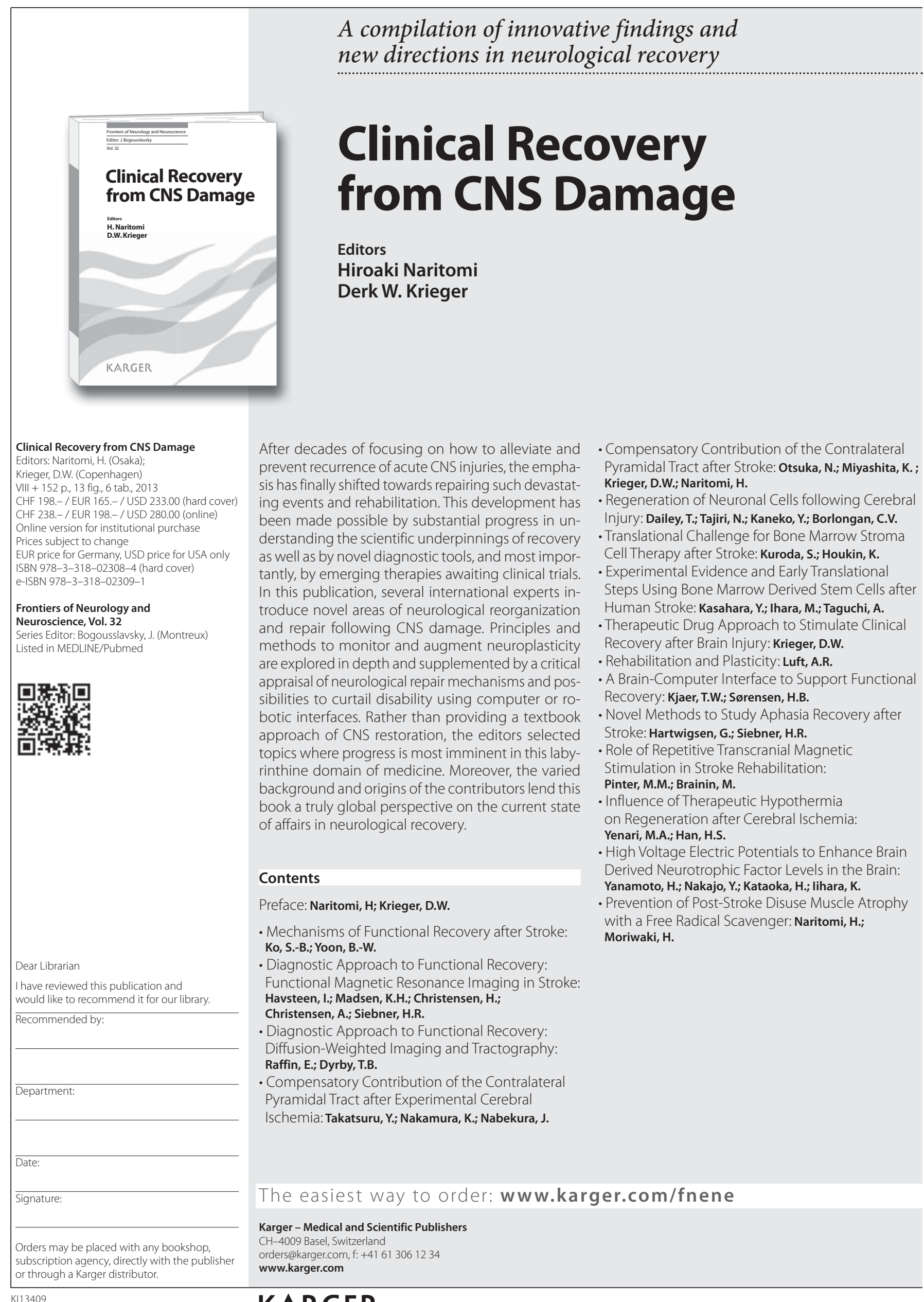




\section{Official Journal of the European Stroke Conference (ESC)}

Official Journal of the European Stroke Organisation (ESO)

\section{Cerebrovascular Diseases}

Founded 1991 by J. Bogousslavsky and M.G. Hennerici

\section{Editor-in-Chief}

M.G. Hennerici, Mannheim

\section{Associate Editors}

H. Adams, Iowa City, Iowa

L.B. Goldstein, Durham, N.C.

L. Hirt, Lausanne

J.-S. Kim, Seoul

Y. Kokubo, Osaka

M.M. Mehndiratta, New Delhi

J.P. Mohr, New York, N.Y.

Y. Shinohara, Tokyo

N. Venketasubramanian, Singapore

\section{Associate Co-Editor}

S. Meairs, Mannheim

\section{Editorial Board}

R.H. Ackerman, Boston, Mass.

F. Aichner, Innsbruck-Igls

A. Alexandrov, Birmingham, Ala.

C. Anderson, Camperdown, N.S.W.

G. Auburger, Frankfurt/M.

H. Ay, Charlestown, Mass.

J. Biller, Maywood, Ill.

N. Bornstein, Tel Aviv

M. Brainin, Tulln

L.R. Caplan, Boston, Mass.

H. Chabriat, Paris

A. Chatzikonstantinou, Mannheim

S. Davis, Melbourne, Vic.

G. de Freitas, Rio de Janeiro

M.S. Dennis, Edinburgh

M. Dichgans, München

H.-C. Diener, Essen

U. Dirnagl, Berlin

D. Droste, Luxembourg

M. Endres, Berlin

F. Fazekas, Graz

V. Feigin, Auckland

J.M. Ferro, Lisbon

N. Futrell, Murray, Utah

A. Gass, Mannheim
S.M. Greenberg, Boston, Mass.

R. Haberl, München

G.J. Hankey, Perth, W.A.

W.-D. Heiss, Köln

M. Hommel, Grenoble

C. Iadecola, New York, N.Y.

L.J. Kappelle, Utrecht

R. Kern, Mannheim

C. Kessler, Greifswald

K. Lees, Glasgow

G.L. Lenzi, Rome

D. Leys, Lille

G.Y.H. Lip, Birmingham

X.-F. Liu, Nanjing

E.H. Lo, Charlestown, Mass.

J.-L. Mas, Paris

A. Massaro, Sao Paulo

H. Mattle, Bern

K. Minematsu, Osaka

J. Montaner, Barcelona

K. Muir, Glasgow

M. Nagayama, Atami

H. Naritomi, Osaka

N. Nighoghossian, Lyon

B. Norrving, Lund
L. Pantoni, Florence

S. Pendlebury, Oxford

N. Poungvarin, Bangkok

S. Ricci, Città di Castello

T. Rundek, Miami, Fla.

R. Sacco, Miami, Fla.

M. Schumacher, Freiburg

S. Schwarz, Mannheim

C. Stapf, Paris

G.K. Steinberg, Stanford, Calif.

K. Szabo, Mannheim

S. Takizawa, Isehara

T. Tatlisumak, Helsinki

D. Toni, Rome

K. Toyoda, Osaka

Y.-K. Tu, Taipei

S. Uchiyama, Tokyo

P. Vajkoczy, Berlin

D. Vivien, Caen

S. Warach, Austin, Tex.

J.M. Wardlaw, Edinburgh

K.E. Wartenberg, Halle

C. Weimar, Essen

L. Wong, Hong Kong
Printed in Switzerland on acid-free and non-aging paper (ISO 9706) by Reinhardt Druck, Basel
Appears monthly: 2 volumes per year (12 issues) 


\section{Cerebrovascular Diseases}

\section{Submission}

Manuscripts written in English should be submitted online:

www.karger.com/ced

Should you experience any problems with your submission, please contact:

\section{ced@karger.com}

Editorial Office 'Cerebrovascular Diseases'

S. Karger AG

P.O. Box

CH-4009 Basel (Switzerland)

Tel. +4161306 1357

Fax +41613061434

Presentation of manuscripts should conform with the Uniform Requirements for Manuscripts Submitted to Biomedical Journals (www.icmje.org).

Recommended reading:

- Alexandrov AV: How to Write a Research Paper. Cerebrovasc Dis 2004;18:135-138

- Alexandrov AV, Hennerici MG: Writing Good Abstracts. Cerebrovasc Dis 2007;23:256-259

- How to Improve the Quality of Reports of parallelgroup randomized trials. The CONSORT Statement. www.consort-statement.org

\section{Conditions}

All manuscripts are subject to editorial review. Manuscripts are received with the explicit understanding that they are not under simultaneous consideration by any other publication. Submission of an article for publication implies transfer of the copyright from the author to the publisher upon acceptance. Accepted papers become the permanent property of Cerebrovascular Diseases and may not be reproduced by any means, in whole or in part, without the written consent of the publisher. It is the author's responsibility to obtain permission to reproduce illustrations, tables, etc. from other publications.

\section{Conflicts of Interest}

Authors are required to disclose any sponsorship or funding arrangements relating to their research and all authors should disclose any possible conflicts of interest. Conflict of interest statements will be published at the end of the article.

\section{Ethics}

Published research must comply with the guidelines for human studies and animal welfare regulations. Authors should state that subjects have given their informed consent and that the study protocol has been approved by the institute's committee on human research. Further, they should also state that animal experiments conform to institutional standards.

\section{Categories of Manuscripts}

Original Papers are full-length research papers which will be considered for the journal. Articles cover topics relevant to clinical studies. Basic and experimental work appear only if directly related to clinical issues (max. 3,000 words).

Reviews are comprehensive, state-of-the-art papers of important clinical problems. Reviews may be invited by the Editor or they may be unsolicited views ( $\max$. 5,000 words). An Abstract is required and should be divided into Background, Summary and Key Messages.

Editorials are usually invited by the Editor (max. 1,000 words). Please send suggestions to the Editor.

Stroke Notes is a category integrating Case Reports, Short Reports, Stroke Vignette, Stroke Opinions. Manu- scripts of max. 500 words, 1 figure or table and max. 10 references are considered for publication provided that they describe a very novel observation or add exceptional pertinent, new information into the mechanisms, diagnosis or treatment of a disease.

Translational Research in Stroke is a new section in the journal publishing reviews on experimental results with direct clinical implications (max. 3,000 words). Articles in this section may be accompanied by an invited comment (max. 1,000 words).

Imaging is a new section in the journal covering timely papers on cerebrovascular imaging by experts in the field (max. 3000 words incl. figures and tables, and max. 40 references). Proposals to the Editor are welcome.

\section{Arrangement}

Title page: The first page of each paper should indicate the title, the authors' names, the institute where the work was conducted, and a short title for use as running head.

Full address: The exact postal address of the corresponding author complete with postal code must be given at the bottom of the title page. Please also supply phone and fax numbers, as well as e-mail address.

Key words: Please supply 3-10 key words in English that reflect the content of the paper.

Abstract: Each paper needs an a detailed and structured abstract of 400 words. This should include the following information: Background: the problem that prompted the study and the purpose of the study; Methods: data sources, subjects, design, measurements, data analysis Results: most important findings; Conclusions: implications, future directions.

Abstracts of Reviews: Should be divided into the following subsections: Background, Summary and Key Messages. The Background should provide a brief clinical context for the review and is followed by the Summary, which should include a concise description of the main topics covered in the text. The Key Messages encapsulate the main conclusions of the review.

Footnotes: Avoid footnotes.

Tables and illustrations: Tables and illustrations (both numbered in Arabic numerals) should be prepared on separate pages. Tables require a heading and figures a legend, also prepared on a separate page. For the reproduction of illustrations, only good drawings and original photographs can be accepted; negatives or photocopies cannot be used. Due to technical reasons, figures with a screen background should not be submitted. When possible, group several illustrations in one block for reproduction ( $\max$. size $180 \times 223 \mathrm{~mm}$ ) or provide crop marks. Electronically submitted b/w half-tone and color illustrations must have a final resolution of $300 \mathrm{dpi}$ after scaling, line drawings one of $800-1,200 \mathrm{dpi}$

\section{Color illustrations}

Online edition: Color illustrations are reproduced free of charge. In the print version, the illustrations are reproduced in black and white. Please avoid referring to the colors in the text and figure legends.

Print edition: Up to 6 color illustrations per page can be integrated within the text at CHF 800.- per page.

\section{References}

In the text identify references by Arabic numerals [in square brackets]. Material submitted for publication but not yet accepted should be noted as [unpublished data] and not be included in the reference list. The list of references should include only those publications which are cited in the text. Do not alphabetize; number references in the order in which they are first mentioned in the text. The surnames of the authors followed by initials should be given. There should be no punctuation other than a comma to separate the authors. Preferably, please cite all authors. Abbreviate journal names according to the Index Medicus system. Also see International Committee of Medical Journal Editors: Uniform requirements for manuscripts submitted to biomedical journals (www.icmje.org).

\section{Examples}

(a) Papers published in periodicals: Chatel J-M, Bernard $\mathrm{H}$, Orson FM: Isolation and characterization of two complete Ara h 2 isoforms cDNA. Int Arch Allergy Immunol 2003;131:14-18.

(b) Papers published only with DOI numbers:

Theoharides TC, Boucher W, Spear K: Serum interleukin-6 reflects disease severity and osteoporosis in mastocytosis patients. Int Arch Allergy Immunol DOI: $10.1159 / 000063858$.

(c) Monographs: Hennerici M, Sitzer G, Weger H-D: Carotid Artery Plaques: Pathogenesis - Development - Evaluation - Treatment. Basel, Karger, 1988.

(d) Edited books: DuBois RN: Cyclooxygenase-2 and colorectal cancer; in Dannenberg AJ, Dubois RN (eds): COX-2. Prog Exp Tum Res. Basel, Karger, 2003, vol 37, pp 124-137.

Reference Management Software: Use of EndNote is recommended for easy management and formatting of citations and reference lists.

\section{Digital Object Identifier (DOI)}

S. Karger Publishers supports DOIs as unique identifiers for articles. A DOI number will be printed on the title page of each article. DOIs can be useful in the future for identifying and citing articles published online without volume or issue information. More information can be found at www.doi.org.

\section{Supplementary Material}

Supplementary material is restricted to additional data that are not necessary for the scientific integrity and conclusions of the paper. Please note that all supplementary files will undergo editorial review and should be submitted together with the original manuscript The Editors reserve the right to limit the scope and length of the supplementary material. Supplementary material must meet production quality standards for Web publication without the need for any modification or editing. In general, supplementary files should not exceed $10 \mathrm{Mb}$ in size. All figures and tables should have titles and legends and all files should be supplied separately and named clearly. Acceptable files and formats are: Word or PDF files, Excel spreadsheets (only if the data cannot be converted properly to a PDF file), and video files (.mov, .avi, .mpeg).

\section{Author's Choice ${ }^{\mathrm{TM}}$}

Karger's Author's Choice ${ }^{\mathrm{TM}}$ service broadens the reach of your article and gives all users worldwide free and full access for reading, downloading and printing at www.Karger.com. The option is available for a onetime fee of CHF 3,000.-, which is a permissible cost in grant allocation. More information can be found at www.karger.com/authors_choice.

\section{NIH-Funded Research}

The U.S. National Institutes of Health (NIH) mandates under the NIH Public Access Policy that final, peerreviewed manuscripts appear in its digital database within 12 months of the official publication date. As a service to authors, Karger submits the final version
KARGER

E-Mail karger@karger.com www.karger.com
(C) 2013 S. Karger AG, Basel 


\section{Cerebrovascular Diseases}

of your article on your behalf to PubMed Central. For those selecting our premium Author's Choice ${ }^{\mathrm{TM}}$ service, the usual embargo will be overriden, accelerating the accessibility of your work. More details on NIH's Public Access Policy are available at http://publicaccess. nih.gov/policy.htm

\section{Self-Archiving}

Karger permits authors to archive their pre-prints (i.e. pre-refereeing) or post-prints (i.e. final draft post-refereeing) on their personal or institution's servers, provided the following conditions are met: Articles may not be used for commercial purposes, must be linked to the publisher's version, and must acknowledge the publisher's copyright. Authors selecting Karger's Au- thor's Choice ${ }^{\mathrm{TM}}$ feature, however, are also permitted to archive the final, published version of their article, which includes copyediting and design improvements as well as citation links.

\section{Page Charges}

There are no page charges for papers of 4 or fewer printed pages (including tables, illustrations and references). Each additional complete or partial page is charged to the author at CHF 325.-. The allotted size of a paper is equal to approx. 13 manuscript pages (including tables, illustrations and references).

\section{Proofs}

Unless indicated otherwise, proofs are sent to the corresponding author and should be returned with the least possible delay. Alterations other than the correction of printer's errors are charged to the author.

\section{Reprints}

Order forms and a price list for reprints are sent with the proofs. Orders submitted after the issue is printed are subject to considerably higher prices.

\section{A new vision to understanding medicine} Handbook of Clinical Gender Medicine

\section{Editors: Karin Schenck-Gustafsson (Stockholm), Paula R. DeCola, Donald W. Pfaff (New York, N.Y.), David S.Pisetsky (Durham N.C.)}

In well-referenced chapters, experts cogently and concisely explain how the incorporation of gender issues into research can affect the medical understanding and treatment of heart disease, osteoporosis, arthritis, pain as well as malaria among other conditions.

This intriguing and unique medical textbook provides readers with a valuable new perspective on how to incorporate gender issues into the different branches of medicine.
Handbook of Clinical Gender Medicine

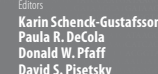

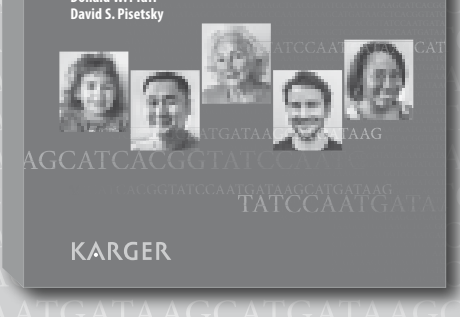

More information and sample essays at: www.karger.com/Gender_Medicine
S. Karger AG, P.O. Box CH-4009 Basel

(Switzerland)

Fax. +41613061234

E-Mail orders@karger.ch www.karger.com
$X V I+522$ p., 62 fig., 4 in color, 63 tab., soft cover, 2012 CHF 69. - / EUR 51. - / USD 69.00 ISBN 978-3-8055-9929-0 e-ISBN 978-3-8055-9930-6

Prices subject to change EUR price for Germany, USD price for USA only

\section{KARGER}

E-Mail karger@karger.com www.karger.com
(C) 2013 S. Karger AG, Basel

The Journal Home Page is available at: www.karger.com/ced 


\section{Cerebrovascular Diseases}

ISSN Print Edition: 1015-9770

ISSN Online Edition: 1421-9786

Journal Homepage: www.karger.com/ced

Publication Data: 'Cerebrovascular Diseases' is published 12 times a year. Volumes 35, 36, each with 6 issues, appear in 2013.

Copyright: (c) 2013 S. Karger AG, Basel (Switzerland). All rights reserved. No part of this publication may be translated into other languages, reproduced or utilized in any form or by any means, electronic or mechanical, including photocopying, recording, microcopying, or by any information storage and retrieval system, without permission in writing from the publisher or, in the case of photocopying, direct payment of a specified fee to the Copyright Clearance Center.

Disclaimer: The statements, opinions and data contained in this publication are solely those of the individual authors and contributors and not of the publisher and the editor(s). The appearance of advertisements in the journal is not a warranty, endorsement, or approval of the products or services advertised or of their effectiveness, quality or safety. The publisher and the editor(s) disclaim responsibility for any injury to persons or property resulting from any ideas, methods, instructions or products referred to in the content or advertisements.
Subscription Rates: Subscriptions run for a full calendar year. Prices are given per year. Personal subscription:

Print or Online

CHF 841.-

EUR 678.-

USD 832.00

Print+Online combined

EUR 756

USD 928.00

postage and handling (added to print and print+online)

CHF 86.40 Europe, CHF 124.80 Overseas

EUR 67.20

USD 115.20

Institutional subscription:

Print or Online

Print+Online combined

CHF 5604.

EUR 4520.-

CHF 6164.-

USD 5548.00

USD 6102.00

postage and handling (added to print and print+online)

CHF 108.- Europe, CHF 156.- Overseas

EUR 84.-

USD 144.00

Airmail surcharge: CHF 105.- / USD 99.00

Subscription included in membership fee for

members of the European Stroke Council (ESC)
Back Volumes and Single Issues: Information on availability and prices of single print issues and print or electronic back volumes can be obtained from Customer Service atservice@karger.com.

Bibliographic Indices: This journal is regularly listed in bibliographic services, including Current Contents ${ }^{\circledR}$ and PubMed/MEDLINE.

Photocopying: This journal has been registered with the Copyright Clearance Center (CCC), as indicated by the code appearing on the first page of each article. For readers in the US, this code signals consent for copying of articles for personal or internal use, or for the personal or internal use of specific clients, provided that the stated fee is paid per copy directly to

Copyright Clearance Center Inc.

222 Rosewood Drive

Danvers, MA 01923 (USA)

A copy of the first page of the article must accompany payment. Consent does not extend to copying for general distribution, for promotion, for creating new works, or for resale. In these cases, specific written permission must be obtained from the copyright owner,

S. Karger AG, P.O. Box

CH-4009 Basel (Switzerland).
Subscription Orders:

Orders can be placed at agencies,

bookstores, directly with the Publisher

\section{S. Karger AG}

Medical and Scientific Publishers

Allschwilerstrasse 10

CH-4009 Basel

Switzerland

$\mathrm{t}:+41613061111$

f: +41613061234

e: karger@karger.com

w: www.karger.com

(for courier services only:

Allschwilerstrasse 10

CH-4055 Basel)

or further Karger offices
or representatives:
Germany
S. Karger GmbH
Postfach
79095 Freiburg
Deutschland
(Hausadresse: Wilhelmstrasse 20A,
79098 Freiburg)
t: +49 76145 20 70
f: +49 7614520714
e: information@karger.de
w: www.karger.de
Japan
Karger Japan, Inc.
Shiba Daimon Asahi Bldg. 2F
1-2-23 Shiba Daimon
Minato-ku
Tokyo $105-0012$
Japan
t: +81 364356242
f: +81 364356244
e: publisher@karger.jp
w: www.karger.jp

USA

S. Karger Publishers, Inc.

26 West Avon Road

P.O. Box 529

Unionville, CT 06085

USA

Toll free: +18008285479

t: +18606757834

f: +18606757302

e: karger@snet.net

France

Librairie Médi-Sciences Sar

36, bd de Latour-Maubourg 75007 Paris

France

$\mathrm{t}: \quad+33(0) 145514258$

f: $+33(0) 145560780$

e: librairie@medi-sciences.fr

w: www.medi-sciences.fr
South East Asia, China and Taiwan

Karger Regional Office (Malaysia)

CEO Suite Kuala Lumpur

Quill 7, 27th Floor

Jalan Stesen Sentral 5

KL Sentral

Kuala Lumpur 50470

Malaysia

t: +60327766803

f: +60327766999

e: service@karger.cn; r.chew@karger.cn

Karger China

10th Floor, Twin Towers (East)

B12 Jianguomenwai Avenue

Beijing 100022

China

t: +861051235033

f: +861051235122

e: service@karger.cn; r.chew@karger.cn

w: www.karger.cn

India, Bangladesh, Sri Lanka

Medscience India

Plot No. 17, Yusuf Sarai Market

B.L. Glass Building, 2nd Floor

Sri Aurobindo Marg

New Delhi 110016

India

t: +911146029633

f: +911146029634

c: +919891052128

e: r.kumar@karger.com

Change of Address:

Both old and new address should be sent

to the subscription source.

\section{KARGER}

E-Mail karger@karger.com www.karger.com
(C) 2013 S. Karger AG, Basel

The Journal Home Page is available at: www.karger.com/ced 


\section{Contents}

See the journal website for contents

KARGER Basel $\bullet$ Freiburg $\cdot$ Paris $\bullet$ London $\bullet$ New York $\cdot$ New Delhi $•$ Bangkok Beijing $\cdot$ Tokyo $\cdot$ Kuala Lumpur $\cdot$ Singapore $\bullet$ Sydney 


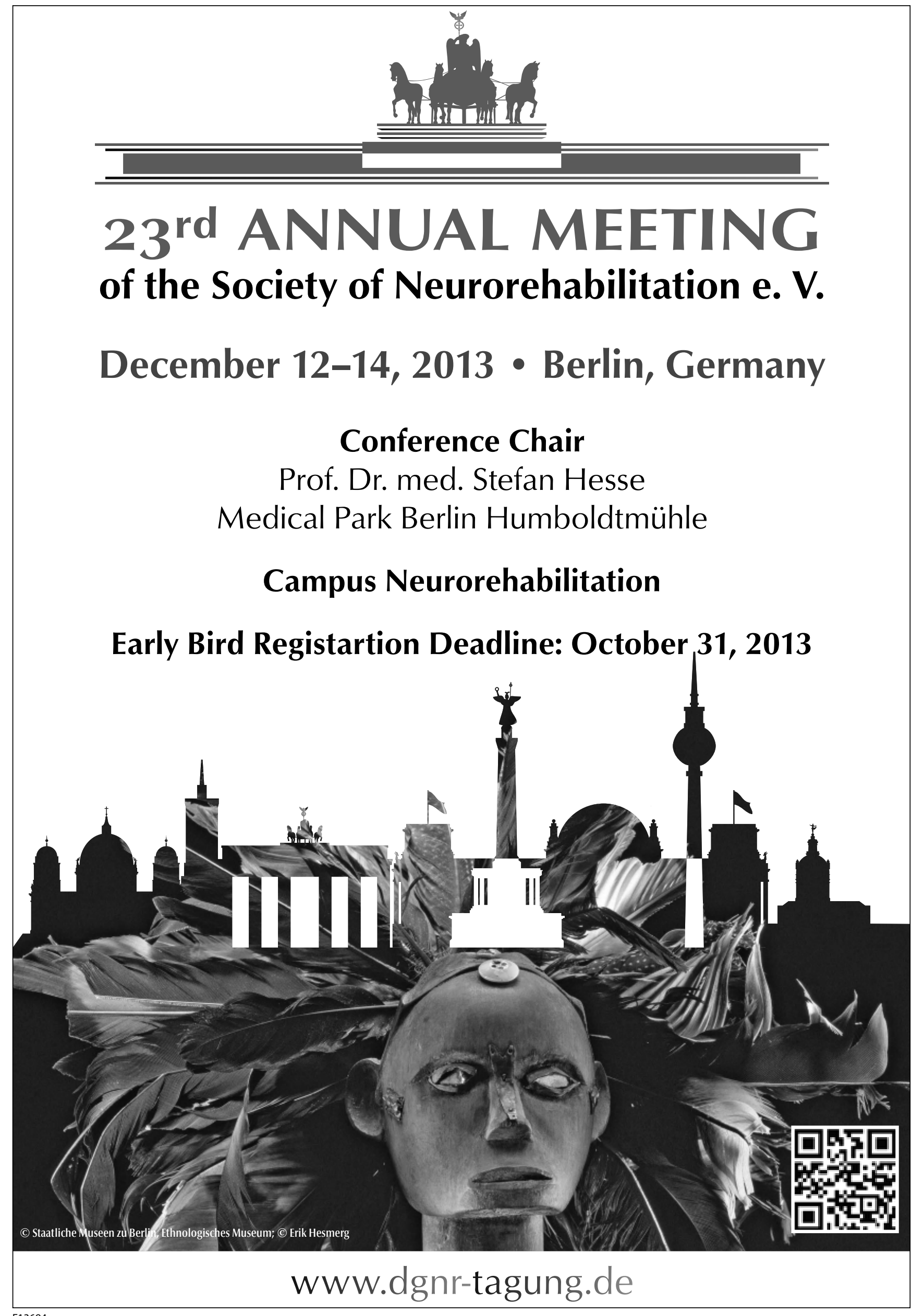




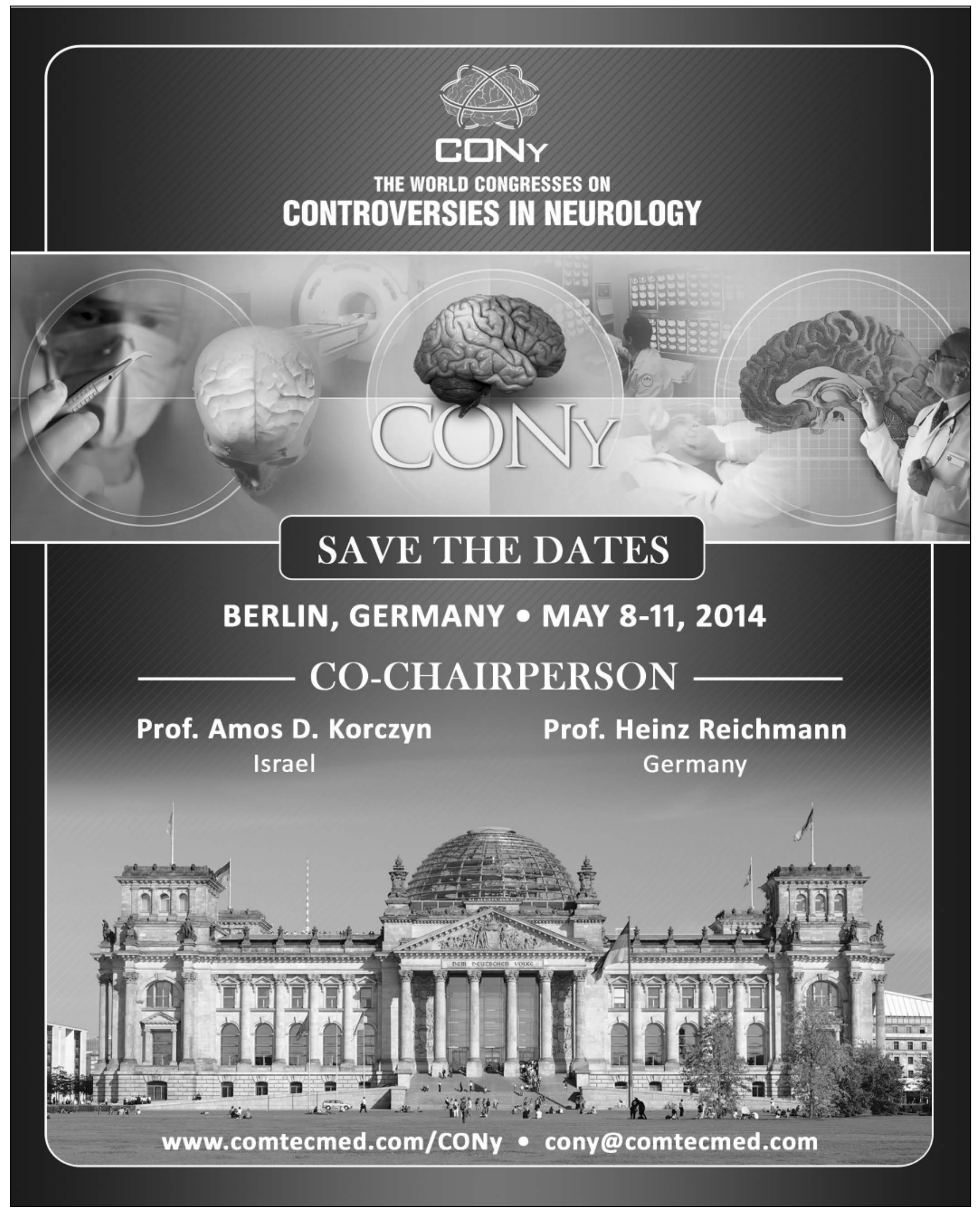




\section{JOINT CONGRESS ISTANBUL 2014}

ISTANBUL, TURKEY, 31 MAY - 3 JUNE 2014

EUROPEAN FEDERATION OF NEUROLOGICAL SOCIETIES EUROPEAN NEUROLOGICAL SOCIETY

We look forward to welcoming you to Istanbul and this unique Congress! Abstract submission deadline: 8 January 2014
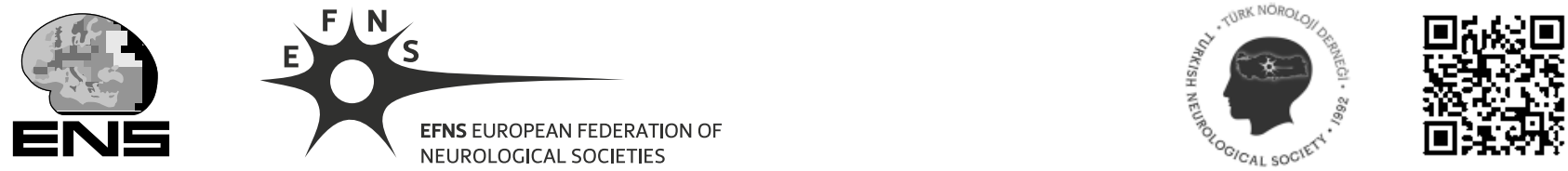
WFNR presents its Biennial Congress

\section{8th World Congress for NeuroRehabilitation}

\section{Towards New Horizons in Neurorehabilitation}

\section{8-12 April 2014, Istanbul, Turkey}

Eminent speakers include:

\section{Professor Leonardo G Cohen}

The concept of neuromodulation

\section{Professor Emilio Bizzi}

Have motor control concepts been useful in neurorehabilitation?

\section{Professor Barbara Wilson}

Cognitive rehabilitation - is it clinically effective and cost-effective?

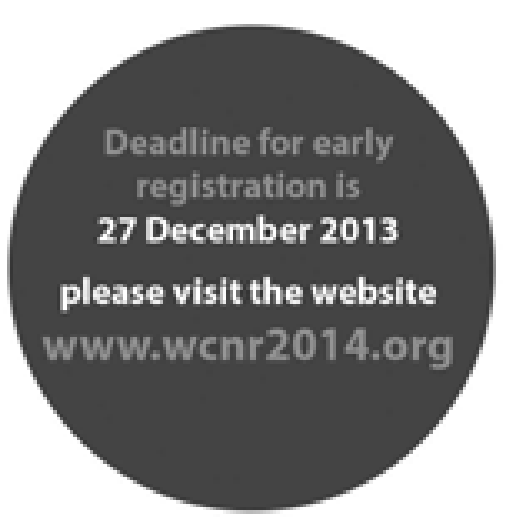

\section{Registration fee includes:}

- Access to all scientific sessions, poster area and exhibitions

- Congress Materials (badge, congress bag, congress handbook)

- Refreshments at morning \& afternoon tea breaks on each day of the congress

- Lunchboxes for the congress

- One (1) ticket to the Welcome Reception.

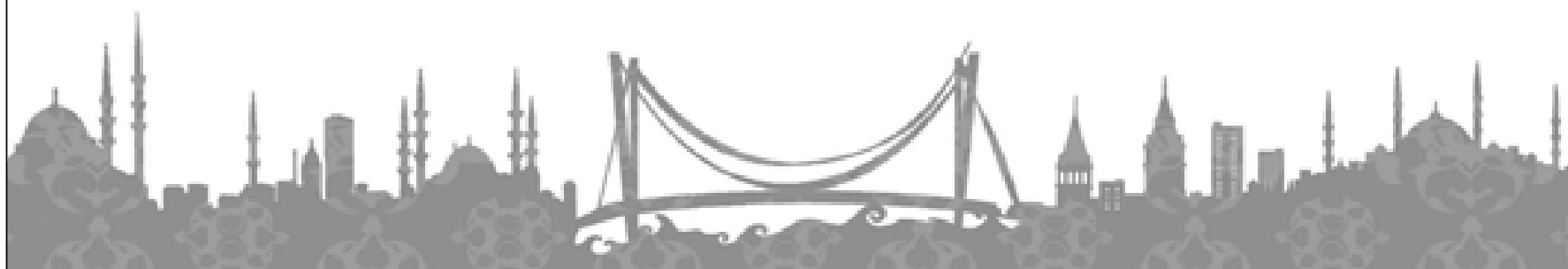




\section{Cerebrovascular Diseases}

(Continued from back cover)

126 Post-Traumatic Stress Disorder in Patients 3 Years after Aneurysmal Subarachnoid Haemorrhage

Visser-Meily, J.M.A.; Rinkel, G.J.E.; Vergouwen, M.D.I. (Utrecht); Passier, P.E.C.A.

(Utrecht/Nieuwegein); van Zandvoort, M.J.E.; Post, M.W.M. (Utrecht)

131 Circulating Markers of Endothelial Dysfunction and Platelet Activation in Patients with Severe Symptomatic Cerebral Small Vessel Disease

Lavallée, P.C.; Labreuche, J.; Faille, D.; Huisse, M.-G.; Nicaise-Roland, P.; Dehoux, M.; Gongora-Rivera, F.; Jaramillo, A.; Brenner, D. (Paris); Deplanque, D. (Lille); Klein, I.-F.; Touboul, P.-J.; Vicaut, E.; Ajzenberg, N. (Paris) on behalf of the Lacunar-B.I.C.H.A.T. Investigators

139 Focal Cortical Subarachnoid Hemorrhage Revealed by Recurrent Paresthesias: A Clinico-Radiological Syndrome Strongly Associated with Cerebral Amyloid Angiopathy

Apoil, M.; Cogez, J. (Caen); Dubuc, L. (Saint-Lô); Bataille, M.; de la Sayette, V. (Caen); Touzé, E. (Caen/Paris); Viader, F. (Caen)

145 Risk of Stroke with Thiazolidinediones: A Ten-Year Nationwide Population-Based Cohort Study

Lu, C.-J.; Sun, Y. (New Taipei City); Muo, C.-H. (Taichung); Chen, R.-C.;

Chen, P.-C. (New Taipei City); Hsu, C.Y. (Taichung)

Stroke Notes

152 The Capsular Warning Syndrome Reconsidered Springer, M.V.; Labovitz, D.L. (Bronx, N.Y.)

153 Hypertrophic Olivary Degeneration after Pontine Hemorrhage: A Cause of Delayed Neurological Deterioration

Menezes Cordeiro, I. (Lisbon/Faro); Tavares, J.B.; Reimão, S.; Geraldes, R.; Ferro, J.M. (Lisbon)

155 Rapid Progression of Unilateral Moyamoya Disease in a Patient with a Family History and an RNF213 Risk Variant

Mineharu, Y. (Kobe/Kyoto); Takagi, Y.; Takahashi, J.C. (Kyoto); Hashikata, H. (Osaka); Liu, W.; Hitomi, T.; Kobayashi, H.; Koizumi, A.; Miyamoto, S. (Kyoto)

158 Reversible Cerebral Vasoconstriction Syndrome after Chewing Khat Leaves Tuladhar, A.M.; Boogaarts, H.D.; de Leeuw, F.-E.; van Dijk, E. (Nijmegen)

160 ESO News 


\section{Cerebrovascular Diseases}

Review

81 Very Small Cerebellar Infarcts: Integration of Recent Insights into a Functional Topographic Classification

De Cocker, L.J.L.; van Veluw, S.J. (Utrecht); Fowkes, M. (New York, N.Y.); Luijten, P.R.; Mali, W.P. Th.M.; Hendrikse, J. (Utrecht)

Original Papers

88 Secondary Prevention of New Vascular Events with Lifestyle Intervention in Patients with Noncardioembolic Mild Ischemic Stroke: A Single-Center Randomized Controlled Trial

Kono, Y.; Yamada, S.; Yamaguchi, J.; Hagiwara, Y.; Iritani, N.; Ishida, S.; Araki, A.; Hasegawa, Y.; Sakakibara, H.; Koike, Y. (Nagoya)

98 Cognitive Patterns in Relation to Biomarkers of Cerebrovascular Disease and Vascular Risk Factors

Miralbell, J. (Barcelona); López-Cancio, E. (Badalona); López-Oloriz, J. (Barcelona); Arenillas, J.F. (Valladolid); Barrios, M.; Soriano-Raya, J.J. (Barcelona); Galán, A.; Cáceres, C. (Badalona); Alzamora, M.; Pera, G.; Toran, P. (Barcelona); Dávalos, A. (Badalona); Mataró, M. (Barcelona)

106 Risk Prediction of Subsequent Early Stroke in Patients with Transient Ischemic Attacks

Chatzikonstantinou, A.; Wolf, M.E.; Schaefer, A.; Hennerici, M.G. (Mannheim)

110 External Validation of the DRAGON Score in an Elderly Spanish Population: Prediction of Stroke Prognosis after IV Thrombolysis

Giralt-Steinhauer, E.; Rodríguez-Campello, A.; Cuadrado-Godia, E.; Ois, Á.; Jiménez-Conde, J.; Soriano-Tárraga, C.; Roquer, J. (Barcelona)

115 The Gap between Trial Data and Clinical Practice - An Analysis of Case Reports on Bleeding Complications Occurring under Dabigatran and Rivaroxaban Anticoagulation

Pfeilschifter, W.; Luger, S.; Brunkhorst, R.; Lindhoff-Last, E.; Foerch, C. (Frankfurt am Main)

120 Slow Sinus Heart Rate as a Potential Predictive Factor of Paroxysmal Atrial Fibrillation in Stroke Patients

Hoshino, T.; Ishizuka, K.; Nagao, T.; Shimizu, S.; Uchiyama, S. (Tokyo) 